University of Cincinnati. He is the first scientist to be named to this post. Mark joined the university in 1977 as a professor of chemistry and served as chairman of the Physical Chemistry Division and later as director of the Polymer Research Center.

A graduate of Wilkes College with a BS degree in chemistry, Mark received his $\mathrm{PhD}$ degree in physical chemistry from the University of Pennsylvania. After serving as a postdoctoral fellow at
Stanford University under Paul J. Flory, Mark was assistant professor of chemistry at the Polytechnic Institute of Brooklyn, and later became a full professor at the University of Michigan. He has also done research and consulting work for industry and has served as a visiting professor at several institutions.

Mark's research interests center around the physical chemistry of polymers, including configuration-dependent properties, conformational energies of

\section{MRS Seeks Graduate Student Award Applications for 1993 Fall Meeting}

At its Fall and Spring Meetings, the Materials Research Society honors outstanding graduate students whose academic achievements and current materials research display a high order of excellence and distinction. The MRS Graduate Student Awards are presented to students of exceptional ability, who show promise for future substantial achievement in materials research.

Eligibility: To qualify for an MRS Graduate Student Award given during the 1993 MRS Fall Meeting, the applicant must be a registered graduate student whose thesis research closely relates to one of the symposium topics addressed in this meeting. The applicant must be the author or co-author of a symposium paper, but need not be the person who presents the paper. MRS membership is not a requirement, but to receive the award, the student must attend this meeting. Students who receive their degrees more than four months prior to the meeting are not eligible.

Procedure: Winners will be selected in two steps. First, a group of finalists will be identified on the basis of information provided in the award application. All finalists will be notified by October 13, 1993 . Second, all finalists must give ten-minute talks based on their symposium papers at a special student presentation session at the 1993 Fall Meeting in Boston. The names of the Graduate Student Award winners will be announced at an Awards Ceremony.

Registration fees for the 1993 Fall Meeting will be paid by MRS for all finalists, entitling them also to membership in MRS for 1994.

Awards: Each winner will receive a $\$ 250$ cash prize and a plaque.

Deadline: All application materials (INCLUDING A COPY OF YOUR ABSTRACT) must be received by MRS headquarters by August 27, 1993.

For information and application forms, contact:

Anne Wagner (GSA-B), Materials Research Society

9800 McKnight Road, Pittsburgh, PA 15237

Phone (412) 367-3003; fax (412) 367-4373. chain molecules, the elasticity of polymer networks, tin-containing polymers, and polymer-coated electrodes. An extensive lecturer in polymer chemistry, he has published more than 350 research papers and co-authored or co-edited seven books. Mark is the editor of the journal Computational Polymer Science and a fellow of the New York Academy of Sciences, the American Physical Society, and the American Association for the Advancement of Science.

Advertisers in This Issue

Page No.

\begin{tabular}{lr}
\hline Bede Scientific & 41,55 \\
\hline CSIR0 & 1 \\
\hline Digital Instruments & 48 \\
\hline Elsevier Science Publishers & 20,54 \\
\hline
\end{tabular}

High Voltage Engineering/

Europa BV inside front cover

Huntington back cover

Lake Shore Cyotronics, Inc. 34

National Electrostatics Corp. 40

Perkin Elmer

56

Philips Semiconductors

15

Spex Industries, Inc. 42

TopoMetrix inside back cover

UTI Instruments Company 50

$\mathrm{VCH}$ 12,17

Virginia Semiconductor, Inc. 16

Voltaix, Inc. 13

For free information about the products and services offered in this issue, fill out and mail the Reader Service Card, or FAX it to (312) 922-3165. 